\title{
Potassium Deficiency Influences Soybean Seed Mineral Compositions and Metabolic Profiles across $\mathrm{CO}_{2}$
}

\author{
Shardendu K. Singh ${ }^{1,2,3^{*}}$, Jinyoung Y. Barnaby ${ }^{1}$, Vangimalla R. Reddy ${ }^{1}$, Richard C. Sicher ${ }^{1}$ \\ ${ }^{1}$ Adaptive Cropping Systems Laboratory, USDA-ARS, Beltsville, MD, USA \\ ${ }^{2}$ School of Environmental and Forest Science, University of Washington, Seattle, WA, USA \\ ${ }^{3}$ Current Address: AeroFarms, Newark, NJ, USA \\ Email: *singh.shardendu@gmail.com
}

How to cite this paper: Singh, S.K., Barnaby, J.Y., Reddy, V.R. and Sicher, R.C. (2019) Potassium Deficiency Influences Soybean Seed Mineral Compositions and Metabolic Profiles across $\mathrm{CO}_{2}$. American Journal of Plant Sciences, 10, 2113-2133. https://doi.org/10.4236/ajps.2019.1012149

Received: August 27, 2019

Accepted: December 3, 2019

Published: December 6, 2019

Copyright (c) 2019 by author(s) and Scientific Research Publishing Inc. This work is licensed under the Creative Commons Attribution International License (CC BY 4.0).

http://creativecommons.org/licenses/by/4.0/

\begin{abstract}
Impacts of potassium $(\mathrm{K})$ deficiency and elevated carbon dioxide $\left(\mathrm{eCO}_{2}\right)$ on seed constituents have rarely been explored in most crops including soybean. A controlled environment experiment was conducted with soybean grown under a sufficient $(5.0 \mathrm{mM})$ and two deficient $(0.50$ and $0.02 \mathrm{mM})$ levels of $\mathrm{K}$ fertilization at ambient $\left(\mathrm{aCO}_{2}\right)$ and $\mathrm{eCO}_{2}\left(400\right.$ and $800 \mu \mathrm{mol} \cdot \mathrm{mol}^{-1}$, respectively). Both treatments significantly affected several constituents, with the $\mathrm{K}$ deficiency having stronger impacts than $\mathrm{eCO}_{2}$. Out of 49 seed constituents, $\mathrm{K}$ deficiency and $\mathrm{eCO}_{2}$ influenced 41 and 16 constituents, respectively. The $\mathrm{K}$ deficiency primarily decreased on average 16 constituents including minerals (e.g., K, P, Mg, Mn, Zn, Fe, B), oil, and essential fatty acids (e.g., linoleic and linolenic acids) but enhanced 25 constituents such as protein, amino acids, simple sugars, and stress-responsive metabolites (e.g., sugar alcohols mannitol and myo-inositol and proline). An accumulation of $\mathrm{N}$ while decreased $\mathrm{C}$ concentration resulted in the lower $\mathrm{C}: \mathrm{N}$ ratio in the seeds of $\mathrm{K}$-deficient plants. However, protein:oil, $\mathrm{C}: \mathrm{K}, \mathrm{N}: \mathrm{P}$, and $\mathrm{N}: \mathrm{K}$ ratios were consistently greater under $\mathrm{K}$ deficiency. The $\mathrm{eCO}_{2}$ also decreased minerals such as $\mathrm{P}, \mathrm{S}$, $\mathrm{Zn}, \mathrm{B}$, and essential fatty acids but enhanced the concentration of six constituents including alanine, oleic acid, fructose, and sugar alcohols across $\mathrm{K}$ fertilization. In addition, the impact of $\mathrm{eCO}_{2}$ on several amino acids appeared to be dependent on the severity of $\mathrm{K}$ deficiency. For instance, $\mathrm{eCO}_{2}$ decreased essential amino acids (e.g., valine, phenylalanine, isoleucine) in the seeds of severely $\mathrm{K}$-deficient plants but not in the other treatments leading to a $\mathrm{K} \times$ $\mathrm{CO}_{2}$ interaction. Results showed that $\mathrm{CO}_{2}$ enrichment is likely to exacerbate the decline in the concentration of seed minerals such as $\mathrm{P}, \mathrm{K}, \mathrm{S}, \mathrm{Zn}$ and $\mathrm{B}$, essential fatty acids, and amino acids under $\mathrm{K}$ limited conditions.
\end{abstract}


Keywords

Amino Acids, Carbohydrates, Glycine max, Mineral Elements, Oil, Essential Fatty Acids

\section{Introduction}

Environmental factors such as crop nutrient status and atmospheric carbon dioxide $\left(\mathrm{CO}_{2}\right)$ concentration have a significant influence on seed composition and nutritional quality [1] [2] [3]. Potassium (K) deficiency occurs in a large area of cropland, which might be attributed to the removal of native soil $\mathrm{K}$ over the years of cropping while inadequate use of supplemental $\mathrm{K}$-fertilizers relative to other macronutrient such as nitrogen $(\mathrm{N})$ and phosphorus $(\mathrm{P})$ [4] [5] [6]. In addition, the current atmospheric $\mathrm{CO}_{2}$ concentration $\left(\approx 400 \mu \mathrm{mol} \cdot \mathrm{mol}^{-1}\right)$ is expected to double at the end of $21^{\text {st }}$ century [7]. In general, $\mathrm{K}$ deficiency decreases while an elevated level of $\mathrm{CO}_{2}\left(\mathrm{eCO}_{2}\right)$ increases plant productivity due to the stimulation of growth and photosynthesis [8]. However, elevated $\mathrm{CO}_{2}$-mediated growth and photosynthetic stimulation are often diminished by plant stressors including K deficiency [9] [10] [11]. Previous reports also indicated alterations in seed compositions of major row crops grown under both the K deficiency [12] [13] [14] and $\mathrm{CO}_{2}$ enrichment [3] [15] [16] [17] [18] [19]. Therefore, it is imperative to understand the interactive impacts of $\mathrm{K}$ deficiency and $\mathrm{eCO}_{2}$ on soybean seed constituents.

$\mathrm{K}$ is the most abundant cation of plant biochemical processes and serves a vital role in maintaining cellular turgidity, assimilates transport, and enzyme activities [20]. K deficiency suppresses plant growth and photosynthetic assimilation across $\mathrm{CO}_{2}$ concentrations in several crops including soybean as reported previously by our groups [10] [11] and other [9] [14] [21]. Moreover, the translocation mechanisms involving phloem loading and transport of metabolites are also interrupted due to tissue low $\mathrm{K}$ concentration, which can lead to impairments in the partitioning and utilization of photosynthates; thus, limiting seed filling processes [22] [23]. The photosynthetic products (e.g., sucrose) play a vital role during soybean seed filling process [24] [25]. Since sucrose is the major form of soluble carbohydrates used in phloem transport and its catabolism is essential for the biosynthesis of a majority of organic molecules such as protein and oil in the seeds, the depressed translocation has profound impacts on the seed composition [22] [26]. Although, both elevated $\mathrm{CO}_{2}$ and $\mathrm{K}$ deficiency influence photosynthesis and seed constituents, impacts of the $\mathrm{K} \times \mathrm{CO}_{2}$ interaction on the soybean seed compositions are still unclear.

Bellaloui et al. [12] reported a lower protein, oleic acid, and isoflavone in soybean seeds grown under low $\mathrm{K}$ fertilization. However, the response of seed metabolic profiles under different $\mathrm{K}$ fertilization regimes have been found vary under field conditions [12] [13] [14], especially due to the interactions with other 
existing factors such as temperature and soil moisture contents in fields [2] [12] [13] [14]. In the controlled environment conditions, we have reported that the deficiency of a given mineral nutrients including $\mathrm{K}$ and phosphorus $(\mathrm{P})$ leads to the alteration in the concentration of several other minerals elements and seed constituents in plant and seed tissues [10] [11] [27]. In the previous report, we found that under $\mathrm{K}$ deficiency the depressed soybean productivity was primarily associated with the decreased growth traits such as plant size and total leaf area than the photosynthetic processes across $\mathrm{CO}_{2}$ levels [11]. We further elaborated that the rate of carbon assimilation was mainly decreased under the severe $\mathrm{K}$ deficiency due to limitation of $\mathrm{CO}_{2}$ diffusion through stomatal and mesophyll pathways [10]. Nevertheless, our research works also revealed that soybean productivity and seed constituent's response to $\mathrm{eCO}_{2}$ was more dependent on the plants nutrient ( $\mathrm{P}$ or K) status [10] [11] [27]. The $\mathrm{eCO}_{2}$ has been known to decrease concentrations of minerals and other biomolecules that is, at least partly, attributed to the 'dilution effects' due to growth stimulation [19]. For example, elevated $\mathrm{CO}_{2}$ caused deficit of minerals such as $\mathrm{N}, \mathrm{P}$, iron, and zinc concentrations, protein, and vitamins in seeds of several crops [3] [15] [16] [17] [18] [19]. Thus, the combined influence of the $\mathrm{K}$ deficiency and $\mathrm{eCO}_{2}$ likely to alter the seed compositions.

There are growing interests among soybean producers and processing industries to improve seed nutritional quality [13] [28]. Soybean is one of the most important crops grown worldwide for food, feed, and fuel [29]. The nutritional quality is often referred by its seed compositions such as concentrations of minerals, protein, and oil, and essential fatty acids and amino acids [1] [29]. Effects of abiotic stresses or elevated $\mathrm{eCO}_{2}$ on crop growth, development, and productivity have been extensively studied as compared with their influence on seed compositions. Studies evaluating the response of soybean seed compositions to $\mathrm{K}$ deficiency are very limited and in combination with $\mathrm{CO}_{2}$, yet to be evaluated [12] [13] [30]. Since $\mathrm{K}$ deficiency and $\mathrm{eCO}_{2}$ are likely to coexist in a natural setting, it is imperative to examine combined effects of these two factors on the seed mineral and metabolic profile. The $\mathrm{K} \times \mathrm{CO}_{2}$ interaction study will provide insight into whether $\mathrm{CO}_{2}$ enrichment will exacerbate the decline in seed constituents under $\mathrm{K}$ limited conditions. The objectives of this study were to determine interactive effects of $\mathrm{K}$ fertilization and $\mathrm{CO}_{2}$ on concentrations of seed mineral elements and metabolic profiles and to establish relationships between seed constituents and plant $\mathrm{K}$ status at the maturity.

\section{Material and Methods}

\subsection{Experimental Conditions and Plant Culture}

An experiment was conducted at the Henry A. Wallace Agricultural Research Center facility, USDA-ARS, Beltsville, Maryland, USA using six controlled environment growth chambers in 2014 (EGC Corp., Chagrin Falls, OH, USA). The experiment was repeated over time in the same year. Soybean (cv. Spencer) was 
planted in 18 pots (one plant per pot, volume $7.6 \mathrm{~L}$ ) filled with quartz silica sand (\#2Q-ROK ${ }^{\circledR}$, US Silica Company, MD, USA) in each chamber. After emergence, the treatments were initiated in a combination of three levels of potassium $(\mathrm{K})$ treatments, a sufficient level as $5.0 \mathrm{mM}$ (control) and two deficient levels as 0.50 $\mathrm{mM}$ (moderate) and $0.02 \mathrm{mM}$ (severe), in a modified Hoagland's nutrient solution each under ambient $\left(\mathrm{aCO}_{2}, 400 \mu \mathrm{mol} \cdot \mathrm{mol}^{-1}\right)$ and elevated $\left(\mathrm{eCO}_{2}, 800\right.$ $\mu \mathrm{mol} \cdot \mathrm{mol}^{-1}$ ) atmospheric $\mathrm{CO}_{2}$ concentrations. Two destructive plant harvests were conducted at 28 and 42 days after planting to avoid plant competition. Thereafter, six plants per chamber were maintained until the soybean maturity. The day/night chamber's air temperature was maintained at $28 / 22^{\circ} \mathrm{C}(12 \mathrm{~h} / 12 \mathrm{~h})$ throughout the experiment. The light as photosynthetically active radiation (PAR) was maintained at plant canopy height to the mean value of $900 \pm 15 \mu \mathrm{mol} \cdot \mathrm{m}^{-2} \cdot \mathrm{s}^{-1}$ using controllable ballasts (Osram Sylvania, MA, USA). Injection of either $\mathrm{CO}_{2}$ or $\mathrm{CO}_{2}$-free air was determined using a TC-2 controller that monitored $\mathrm{CO}_{2}$ every 3 s, measured from an absolute infrared gas analyzer (WMA-4PP-systems, Haverhill, MA, USA). The relative humidity was not controlled and varied between $50 \%$ and $70 \%$ among chambers. More details of the experimental conditions have been reported previously by Singh and Reddy [11].

\subsection{Determination of Tissue Mineral Elements}

At maturity, plants were harvested and separated into plant organs of leaves, roots, stems, and pods. All plant parts, except the pods, were dried to a constant weight at $70^{\circ} \mathrm{C}$. Pods were dried at $35^{\circ} \mathrm{C}$ in a forced-ventilation air for 10 days then the seeds were separated from pods. Dry weight of plant components and seeds were measured separately. The plant components and seed were ground using a Wiley Mill (Wiley ${ }^{\circledR}$ Mill, Thomas Scientific, NJ, USA) to pass through a $1 \mathrm{~mm}$ screen. The plant tissue $\mathrm{K}$ concentration and concentrations of seed mineral elements of phosphorus $(\mathrm{P}), \mathrm{K}$, calcium $(\mathrm{Ca})$, magnesium $(\mathrm{Mg})$, sulfur $(\mathrm{S})$, iron $(\mathrm{Fe})$, manganese $(\mathrm{Mn})$, zinc $(\mathrm{Zn})$, copper $(\mathrm{Cu})$, and boron $(\mathrm{B})$ were determined using Spectro ARCOS EOP-Inductively Coupled Plasma (ICP) Spectrophotometer (Spectro Analytical Instruments, Mahwah, NJ, USA) at the Agriculture Diagnostic Laboratory, University of Arkansas, Fayetteville, AR, USA, according to the standard procedure [31]. The concentrations of seed carbon (C) and nitrogen $(\mathrm{N})$ were determined by combustion of the ground materials using a CHN-2000 (Carbon Hydrogen Nitrogen-2000: LECO Corporation, St. Joseph, MI, USA) at the Adaptive Cropping System Laboratory, USDA-ARS, Beltsville, $\mathrm{MD}$, USA. The weighted plant (whole-plant) $\mathrm{K}$ concentration was determined as the sum of the products of the dry mass of plant and seed, and their K concentration divided by the total dry mass [32].

\subsection{Determination of Seed Metabolite Concentrations}

The seed metabolic profiles were determined in $30 \mathrm{mg}$ of ground seed materials from each plant. The pulverized seed material was suspended in $1.4 \mathrm{~mL}$ of $70 \%$ 
ice-cold methanol containing a final concentration of $2.5 \mathrm{mmol} \cdot \mathrm{L}^{-1} \alpha$-aminobutyric acid and $2 \mathrm{mg} \cdot \mathrm{mL}^{-1}$ ribitol as internal standards. The suspended samples were vortexed vigorously, allowed to stand at room temperature for $30 \mathrm{~min}$ and then centrifuged as described previously (Sicher, 2008). The pellets were extracted again with $1.4 \mathrm{ml}$ of the above solvent, incubated in shaker bath for $15 \mathrm{~min}$ at $45^{\circ} \mathrm{C}$, kept at room temperature for $30 \mathrm{~min}$ and centrifuged as above. The supernatants were combined in a $15 \mathrm{~mL}$ Falcon tube and stored at $-20^{\circ} \mathrm{C}$ to be used for the determination of metabolic profile as described previously by our group [33].

In brief, the soluble carbohydrates and derivative (sucrose, glucose, fructose, maltose, ribose, myo-inositol-inositol, pinitol, and mannitol), organic acids (citrate, aconitate, succinate, fumarate, malate, pyruvate, Oxalic, shikimate, glycerate, adipic, and malonic), and amino acids (valine, phenylalanine, leucine, isoleucine, threonine, glycine, glutamine, proline, alanine, serine, and putrescine) were measured by gas chromatography (HP/Agilent 6890A, Agilent Technologies, Wilmington, DE) coupled to mass spectrometry. A $10 \mu \mathrm{L}$ aliquot of each extract was transferred in a $1 \mathrm{~mL}$ reactivial and dried overnight under vacuum. The dried samples were dissolved in $100 \mu \mathrm{L}$ of pyridine containing $20 \mathrm{mg} \cdot \mathrm{ml}^{-1}$ methoxyamine and the vials were incubated in a shaker bath for $90 \mathrm{~min}$ at $30^{\circ} \mathrm{C}$. Subsequently, $100 \mu \mathrm{l}$ of $\mathrm{N}$-methyl-N-(trimethylsilyl) fluoroacetamide (MSTFA) was added to each vial, which was subsequently incubated in shaker bath for 30 $\min$ at $37^{\circ} \mathrm{C}$.

\subsection{Determination of Seed Protein, Oil, and Fatty Acid Concentrations}

Concentrations of seed protein and oil were determined non-destructively using near infrared (NIR) spectroscopy in a $25 \mathrm{~g}$ sample of randomly chosen mature soybean seeds (moisture 13\%) from each plant. The NIR analyses were performed by the National Center for Agricultural Utilization Research (NCAUR), USDA-ARS, Peoria, IL, USA. The concentrations of saturated fatty acids palmitic (C16:0) and stearic (C18:0) and unsaturated fatty acids oleic (C18:1), linoleic (C18:2), and linolenic (C18:3) of the total seed oil from three randomly selected seeds from each plant were determined by gas chromatography (GC) at the same facility as described by Singh et al. [34]. In brief, seeds were hammer-cracked manually (not pulverized) and the oil was extracted by soaking overnight in closed vials containing $1.5 \mathrm{ml}$ of a mixture of $\mathrm{CHCl}_{3}: \mathrm{Hexane:MeOH}(8: 5: 2 \mathrm{v}: \mathrm{v}: \mathrm{V})$. Then, $0.1 \mathrm{ml}$ of sodium methoxide $(\sim 0.35 \mathrm{M})$ solution and $0.5-1.0 \mathrm{ml}$ of the extraction fluid were added and vials placed into the GC auto-sampler. Samples were analyzed on a GC (Agilent 6890 GC with an Agilent J\&W GC column, Quantum Analytics, Inc., Foster City, CA) equipped with a flame ionization detector $\left(320^{\circ} \mathrm{C}, \mathrm{H}_{2}\right.$ @ $35 \mathrm{~mL} / \mathrm{min}$, air @ $400 \mathrm{~mL} / \mathrm{min}$, makeup gas of $\mathrm{N}_{2} @ 25 \mathrm{~mL} / \mathrm{min}$ ).

\subsection{Data Analysis}

The SAS software (SAS Enterprise Guide, 4.2, SAS Institute Inc., NC, USA) was 
used for the statistical analysis. To test treatment effects and their interaction, PROC MIXED procedure with Kenward-Rogers (kr) adjustment of degrees of freedom was used for analysis of variance (ANOVA) using the mean value for a given seed component from each repetition of the experiment. Treatments $(\mathrm{K}$ and $\mathrm{CO}_{2}$ ) and their interaction were considered as fixed effects and repetition of the experiment as a random effect. The ANOVA significance levels ( $P$-values) are presented as ${ }^{\star},{ }^{* *},{ }^{* *}$ and ${ }^{\mathrm{ns}}$ representing $P \leq 0.05, P \leq 0.01, P \leq 0.001$, and non-significant i.e., $P>0.05$, respectively.

Seed minerals elements and metabolic profile were also regressed against the plant tissue $\mathrm{K}$ concentration using the values from individual plant from each experiment across $\mathrm{K}$ treatment. The PROC MIXED procedure of SAS was used to select the best regression fit (quadratic versus linear) using 'Akaike information criterion' (AIC, lower is better), and to test the uniformity of coefficients of regression analysis between two $\mathrm{CO}_{2}$ levels. In case the quadratic term or the slope (i.e., linear regression) significantly differed at alpha $\leq 0.05$ between $\mathrm{CO}_{2}$ levels, a regression relationship was established separately for each $\mathrm{CO}_{2}$ level. Alternatively, the relationship was established across $\mathrm{CO}_{2}$. The PROC REG and PROC GLM procedures were used for regression analysis to determine the level of the significance ( $P$-value) and the coefficient of determination $\left(\mathrm{r}^{2}\right)$. The significance is presented as ${ }^{*},{ }^{* *},{ }^{* *}$ and ${ }^{\text {ns }}$ indicating $P \leq 0.05, P \leq 0.01, P \leq 0.001$, non-significant $(P>0.05)$, respectively.

\section{Results}

\section{1. $\mathrm{K}$ and $\mathrm{CO}_{2}$ Effects on Seed Mineral Elements}

$\mathrm{K}$ deficiency significantly affected nine out of 12 seed mineral elements (Figure 1). Across $\mathrm{CO}_{2}$ levels, several of these mineral elements declined under $\mathrm{K}$ deficiency compared to control, except $\mathrm{N}$ and $\mathrm{Cu}$. The decline was relatively greater under the severe $\mathrm{K}$ deficiency. Seed $\mathrm{C}$ concentration decreased from an average value of $495.5 \mathrm{mg} \cdot \mathrm{g}^{-1}$ to $479.5 \mathrm{mg} \cdot \mathrm{g}^{-1}$, especially under severe $\mathrm{K}$ deficiency, across $\mathrm{CO}_{2}$ levels. Among primary macronutrients, seed $\mathrm{N}$ increased $13 \%-15 \%$ while $\mathrm{P}$ and $\mathrm{K}$ declined $2.5 \%-9.2 \%$ and $24 \%-38 \%$, respectively, under $\mathrm{K}$ deficiency when averaged across $\mathrm{CO}_{2}$ levels (Figure 1). The ratios among concentrations of primary macronutrient and $\mathrm{C}$ were also significantly affected by $\mathrm{K}$ treatment, except the C:P ratio. On average, $\mathrm{K}$ deficiency decreased C:N ratio $\approx 14 \%$ while increased C:K, N:P, and N:K ratios about 21-68\% (Figure 1). Among secondary macronutrients, a significant $\mathrm{K}$ effect was mainly observed for $\mathrm{Mg}$ that was decreased by $27 \%-45 \%$ under $\mathrm{K}$ deficiency. The concentration of micronutrients $\mathrm{Mn}$ and B declined on average 11\% - 19\% under K deficiency. Averaged across $\mathrm{CO}_{2}$ levels, $\mathrm{Zn}$ concentration declined $15.5 \%$ primarily under moderate $\mathrm{K}$ deficiency. However, $\mathrm{Cu}$ increased $\approx 47 \%$, especially under severe $\mathrm{K}$ deficiency. A significant $\mathrm{K} \times \mathrm{CO}_{2}$ interaction was observed for $\mathrm{B}$ concentration and $\mathrm{N}: \mathrm{P}$ ratios (Figure 1). The $\mathrm{eCO}_{2}$ significantly decreased concentrations of $\mathrm{P}, \mathrm{S}, \mathrm{Zn}$, and $\mathrm{B}$ with the minimum and maximum decline of $8 \%$ and $21 \%$ for $S$ and $B$, respectively, 

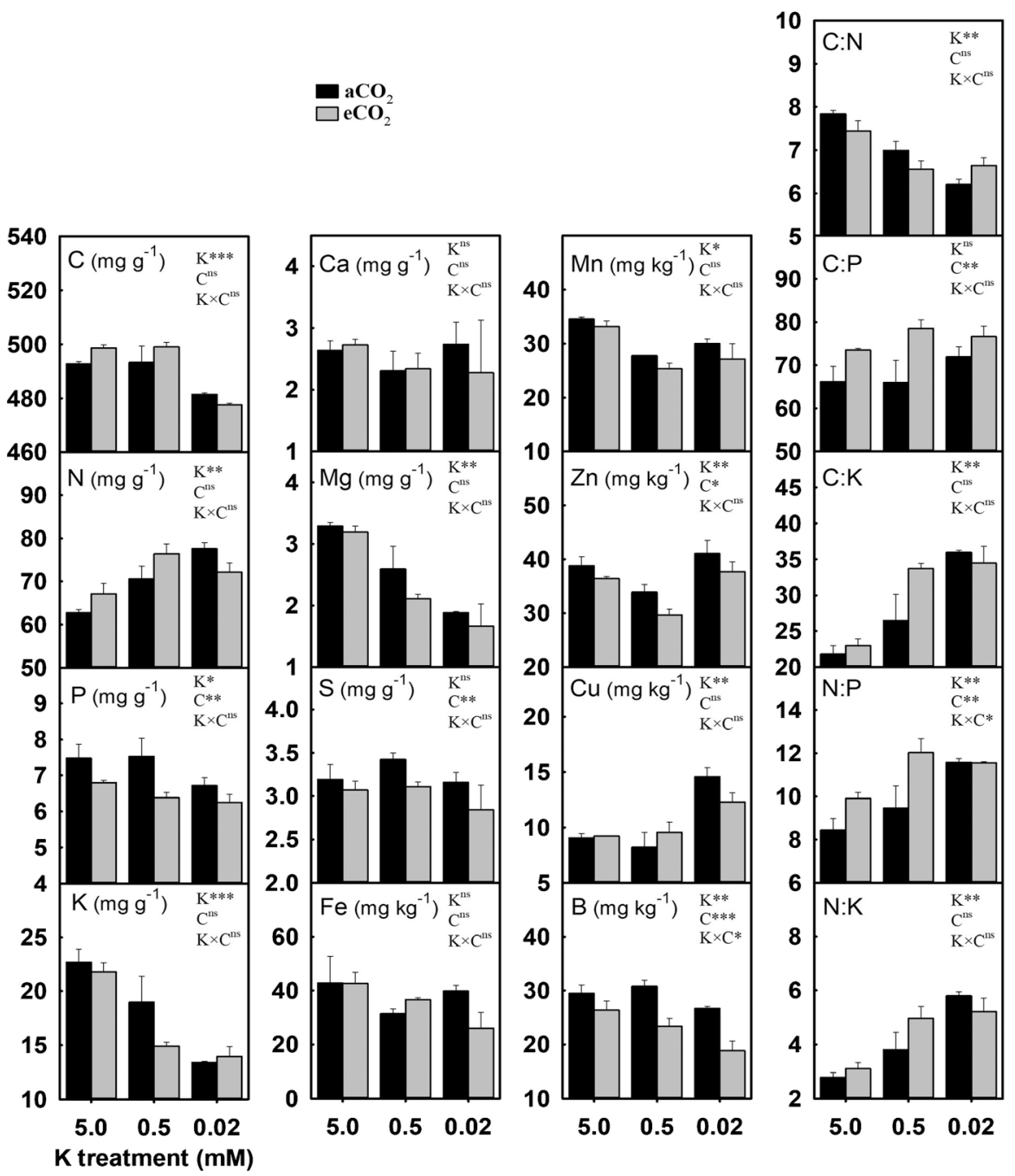

Figure 1. Potassium (K) treatment effects on the concentration of mineral elements in soybean seeds grown and harvested under ambient $\left(\mathrm{aCO}_{2}, 400 \mu \mathrm{mol} \cdot \mathrm{mol}^{-1}\right.$, black bars) and elevated $\left(\mathrm{eCO}_{2}, 800 \mu \mathrm{mol} \cdot \mathrm{mol}^{-1}\right.$, grey bars) $\mathrm{CO}_{2}$ levels. $\mathrm{C}$, carbon; $\mathrm{N}$, nitrogen; $\mathrm{P}$, phosphorus; $\mathrm{K}$, potassium; and ratios between; $\mathrm{Ca}$, calcium; $\mathrm{Mg}$, magnesium; $\mathrm{S}$, sulfur; $\mathrm{Fe}$, iron; $\mathrm{Mn}$, manganese; $\mathrm{Zn}$, zinc; $\mathrm{Cu}$, copper; $\mathrm{B}$, boron. The analysis of variance for treatment effects $\left(\mathrm{K}\right.$ and $\left.\mathrm{CO}_{2}, \mathrm{C}\right)$ and their interaction $(\mathrm{K} \times \mathrm{C})$ are also shown by significance levels, where ${ }^{*},{ }^{* *},{ }^{* *}$ and ${ }^{\mathrm{ns}}$ indicate $\mathrm{P} \leq 0.05, P \leq 0.01, P \leq 0.001$, non-significant $(P>$ $0.05)$, respectively. Bars represent mean \pm se $(\mathrm{n}=2$, averaged across the repeated experiment).

when averaged across $\mathrm{K}$ levels. Conversely, $\mathrm{eCO}_{2}$ increased $\mathrm{C}: \mathrm{P}$ and $\mathrm{N}: \mathrm{P}$ ratios by $11 \%-27 \%$, particularly under the control and moderate K deficiency.

\section{2. $\mathrm{K}$ and $\mathrm{CO}_{2}$ Effects on Seed Amino Acids}

The concentration amino acids were significantly affected by $\mathrm{K}$ treatment and consistently increased under $\mathrm{K}$ deficiency across $\mathrm{CO}_{2}$ levels, except glutamine (Figure 2). However, these increases were of greater magnitudes (3 - 18 folds relative to control) under severe $\mathrm{K}$ deficiency. The $\mathrm{K} \times \mathrm{CO}_{2}$ interaction was significant for valine, phenylalanine, isoleucine, glycine, proline, and serine. Aver- 
aged cross $\mathrm{CO}_{2}$, essential amino acids valine, phenylalanine, leucine, isoleucine, and, threonine concentrations were enhanced $24 \%-72 \%$ under moderate $\mathrm{K}$ deficiency and $277 \%$ - 1600\% under severe K deficiency compared to control, with threonine showing the greatest enhancement. The non-essential amino acids glycine, proline, alanine, and serine had $6 \%$ - 75\% greater values under moderate $\mathrm{K}$ deficiency than control average across $\mathrm{CO}_{2}$ levels. However, under severe $\mathrm{K}$ deficiency, these amino acids were approximately $300 \%-1700 \%$ greater than control, with serine and alanine having the highest and lowest increment, respectively. The $\mathrm{CO}_{2}$ effect was also significant for phenylalanine, alanine, and serine (Figure 2). Relative to $\mathrm{aCO}_{2}$, the $\mathrm{eCO}_{2}$ decreased phenylalanine and serine concentrations by $20 \%-40 \%$, especially under severe K deficiency. Conversely, $\mathrm{eCO}_{2}$ stimulated alanine concentration by $36 \%$ under the similar situation.

\section{3. $\mathrm{K}$ and $\mathrm{CO}_{2}$ Effects on Protein, Oil, and Fatty Acids}

The concentrations of protein, oil, and fatty acids were assessed mainly between the control and moderate $\mathrm{K}$ deficiency across $\mathrm{CO}_{2}$ levels due to very low production of seeds under the lowest $\mathrm{K}$ treatments, which were mostly used for the seed mineral and metabolic profiling (Figure 3). The seed production across these
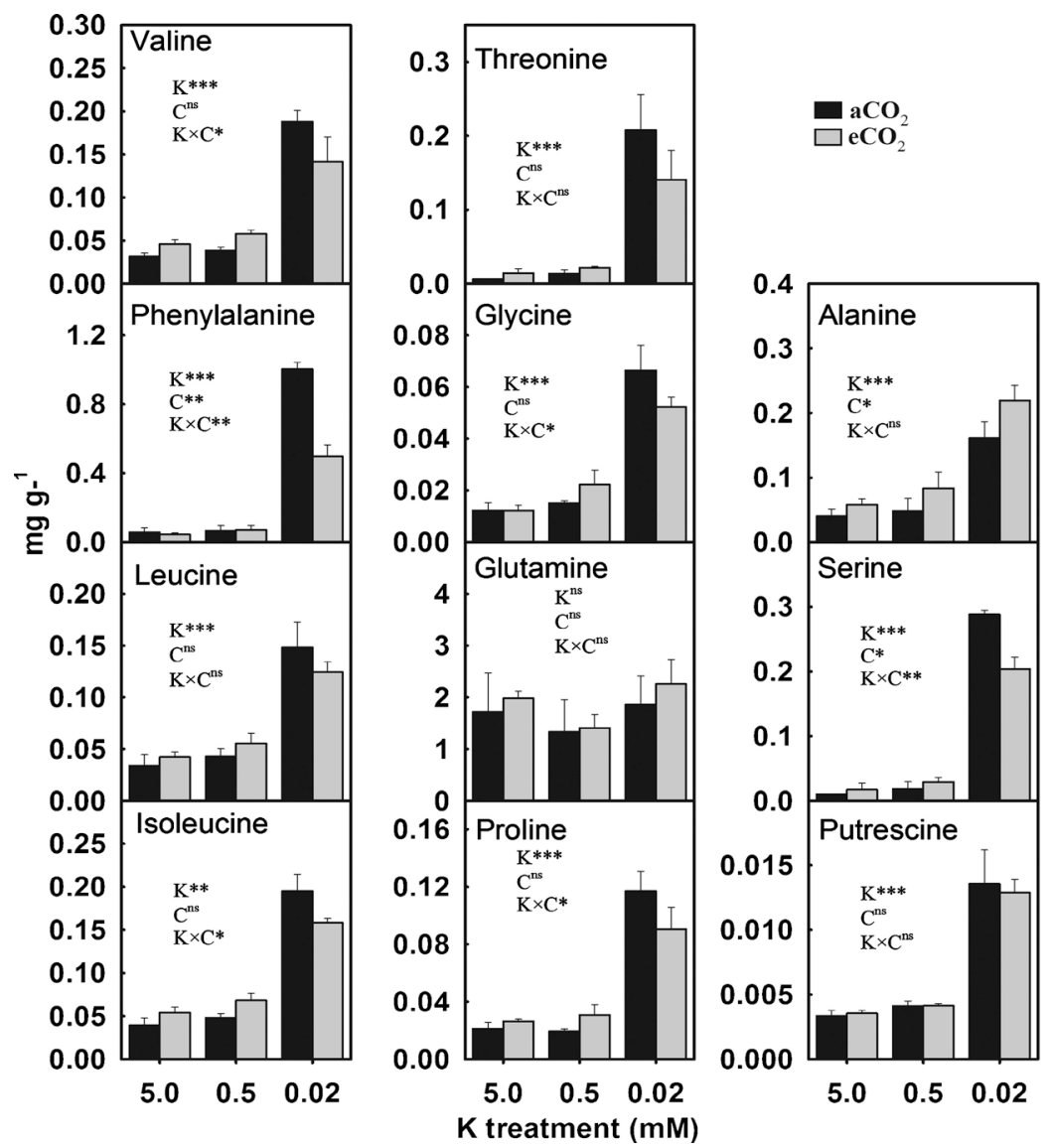

Figure 2. Potassium (K) treatment effects on the concentration of amino acids in soybean seeds grown and harvested under ambient $\left(\mathrm{aCO}_{2}, 400 \mu \mathrm{mol} \cdot \mathrm{mol}^{-1}\right.$, black bars $)$ and elevated $\left(\mathrm{eCO}, 800 \mu \mathrm{mol} \cdot \mathrm{mol}^{-1}\right.$, grey bars $) \mathrm{CO}_{2}$ levels. Other details are as in Figure 1. 

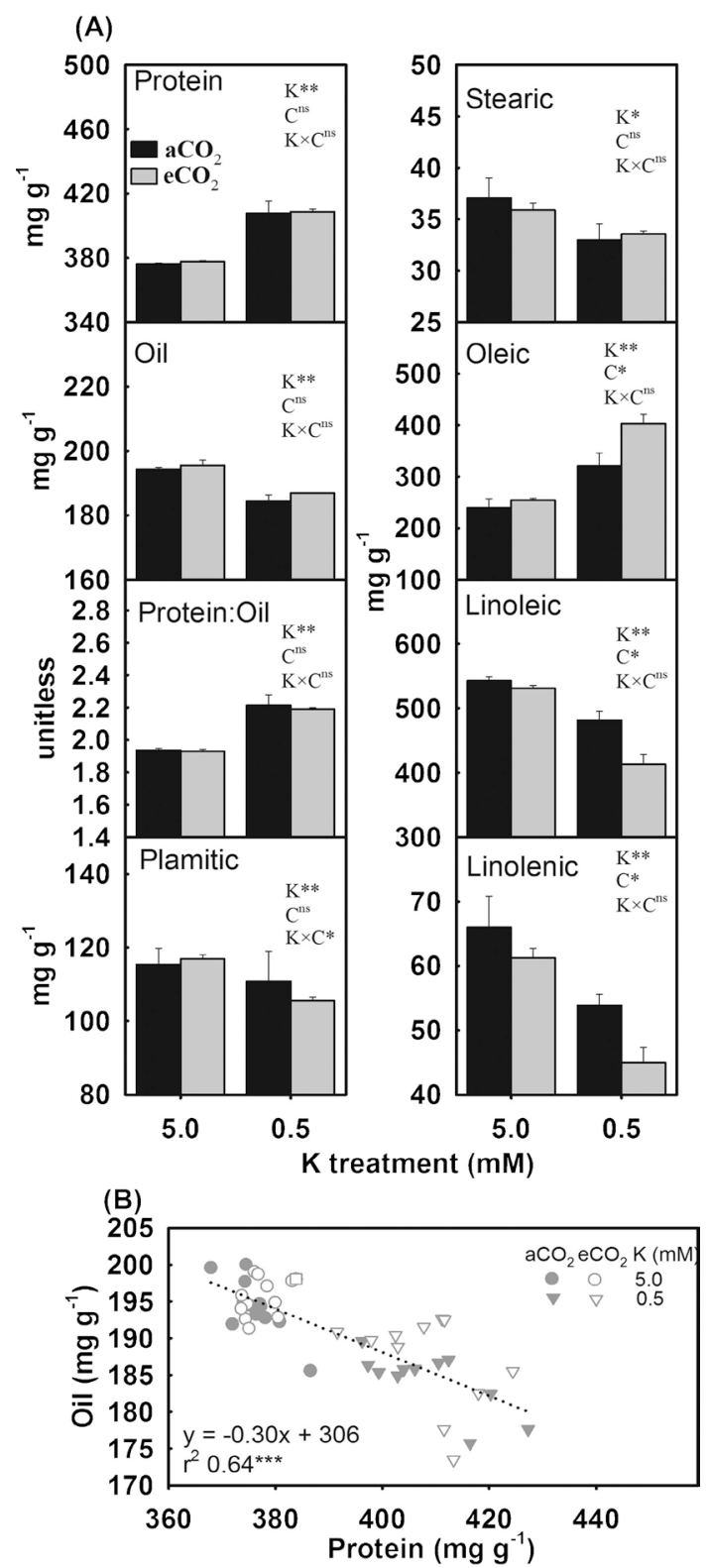

Figure 3. Potassium (K) treatment effects on the concentration of (A) protein, oil, and fatty acids and (B) the relationship between seed oil and protein in soybean seeds grown under ambient $\left(\mathrm{aCO}_{2}, 400 \mu \mathrm{mol} \cdot \mathrm{mol}^{-1}\right.$, black bars $)$ and elevated $\left(\mathrm{eCO}_{2}, 800 \mu \mathrm{mol} \cdot \mathrm{mol}^{-1}\right.$, grey bars) $\mathrm{CO}_{2}$ levels. The line (B) is linear regression fit across $\mathrm{CO}_{2}$ levels. Other details are as in Figure 1.

treatments have been reported previously (Singh and Reddy 2017). The effect of $\mathrm{K}$ was significant for these seed components. Averaged between $\mathrm{CO}_{2}$ levels, concentrations of protein and oil increased and decreased by $8.3 \%$ and $4.5 \%$ under moderate $\mathrm{K}$ deficiency, respectively, compared to control (Figure $3(\mathrm{~A})$ ). The $\mathrm{K}$ deficiency also increased protein:oil ratio by $14 \%$ across $\mathrm{CO}_{2}$ levels. Concentrations of both saturated fatty acids, palmitic and stearic acids, decreased 7\% - 8\% under moderate $\mathrm{K}$ deficiency, when averaged across $\mathrm{CO}_{2}$ levels. However, that of mono-unsaturated fatty acid, oleic acid, was increased under moderate $\mathrm{K}$ defi- 
ciency by $34 \%$ and $58 \%$ under $\mathrm{aCO}_{2}$ and $\mathrm{eCO}_{2}$, respectively. Conversely, under moderate $\mathrm{K}$ deficiency, essential fatty acids (i.e., linoleic and linolenic acids), declined by $11 \%-17 \%$ and $22 \%-26 \%$ under $\mathrm{aCO}_{2}$ and $\mathrm{eCO}_{2}$, respectively. The $\mathrm{eCO}_{2}$ significantly increased oleic acid by $25 \%$ while decreased linoleic acid by $14 \%$, particularly under the moderate $\mathrm{K}$ deficiency (Figure $3(\mathrm{~A})$ ). There was an inverse linear relationship between seed protein and oil concentration when regressed across the $\mathrm{CO}_{2}$ levels (Figure 3(B)).

\section{4. $\mathrm{K}$ and $\mathrm{CO}_{2}$ Effects on Seed Soluble Carbohydrates}

Among the soluble carbohydrates in soybean seeds, sucrose was the most abundant followed by pinitol (Figure 4). Relative to control, $\mathrm{K}$ deficiency decreased sucrose concentration by $16 \%-40 \%$ averaged across $\mathrm{CO}_{2}$ levels. However, concentrations of soluble sugars, glucose, fructose, and ribose, were more than doubled, particularly under severe $\mathrm{K}$ deficiency. Maltose was not significantly affected by the treatments. Averaged between $\mathrm{CO}_{2}$ levels, sugar alcohols, myoinositol and mannitol, also increased $51 \%$ - 200\% under moderate $\mathrm{K}$ deficiency and $350 \%-1000 \%$ under severe $\mathrm{K}$ deficiency compared to control. The sugar

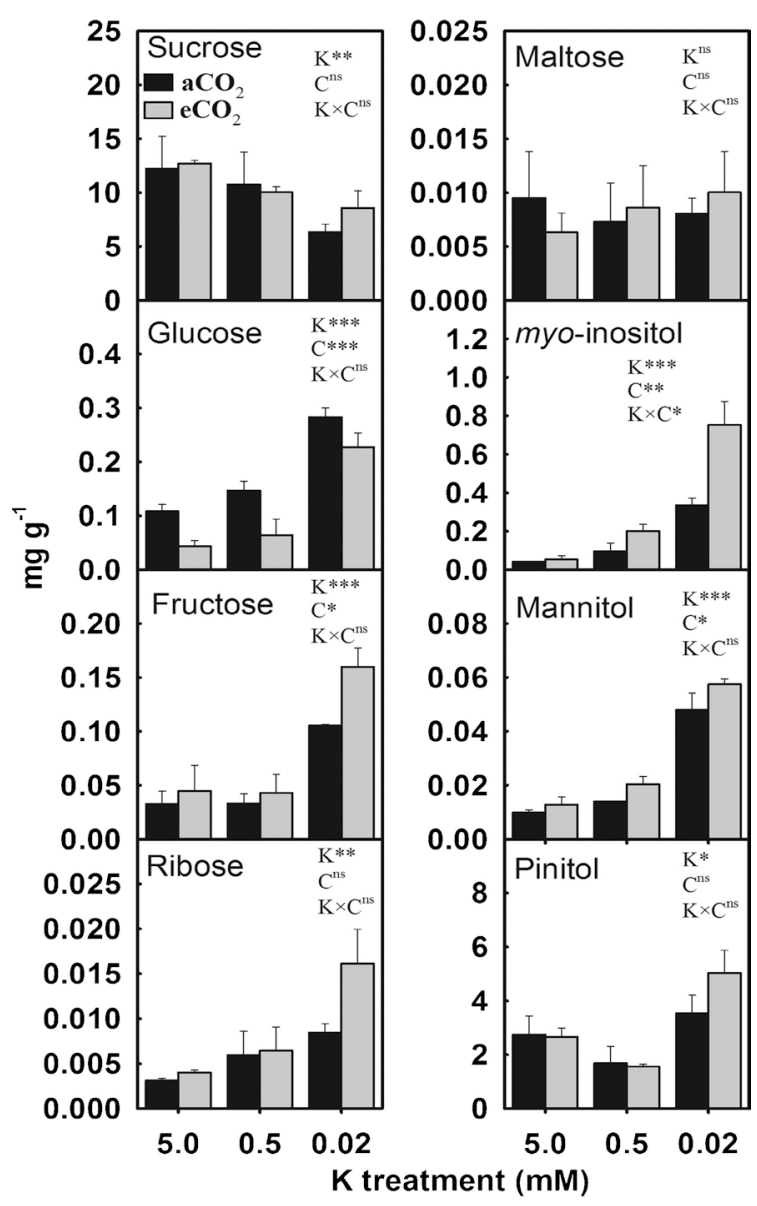

Figure 4. Potassium (K) treatment effects on the concentration of carbohydrates in soybean seeds grown under ambient $\left(\mathrm{aCO}_{2}, 400 \mu \mathrm{mol} \cdot \mathrm{mol}^{-1}\right.$, black bars $)$ and elevated $\left(\mathrm{eCO}_{2}\right.$, $800 \mu \mathrm{mol} \cdot \mathrm{mol}^{-1}$, grey bars) $\mathrm{CO}_{2}$ levels. Other details are as in Figure 1. 
alcohol, pinitol, decreased about $40 \%$ then increased by $58 \%$ under moderate and severe $\mathrm{K}$ deficiency, respectively. The effect of $\mathrm{CO}_{2}$ was significant for glucose, fructose, myo-inositol, and mannitol (Figure 4). Seed glucose concentration consistently decreased $20 \%-60 \%$ under $\mathrm{eCO}_{2}$ versus $\mathrm{aCO}_{2}$ across $\mathrm{K}$ levels. However, fructose concentration increased $29 \%-52 \%$ under $\mathrm{eCO}_{2}$. Relative to the $\mathrm{aCO}_{2}$ level, $\mathrm{eCO}_{2}$ also increased concentration of myo-inositol by $23 \%$ $124 \%$ and mannitol by $28 \%-45 \%$ across $\mathrm{K}$ levels, but these increases were the greatest under severe $\mathrm{K}$ deficiency (Figure 4).

\section{5. $\mathrm{K}$ and $\mathrm{CO}_{2}$ Effects on Seed Organic Acids}

Majority of the measured organic acids were significantly affected by $\mathrm{K}$ treatments while the effect of $\mathrm{CO}_{2}$ was mainly significant for aconitate and pyruvate (Figure 5). Averaged between $\mathrm{CO}_{2}$ levels, concentration of tricarboxylic acid (TCA) cycle intermediates, citrate, fumarate, and malate, consistently declined about $42 \%-72 \%$ under K deficiency whereas TCA intermediates, aconitate and pyruvate, increased $114 \%$ - 200\%, especially under severe K deficiency. The TCA intermediates, succinate and oxalic acid, were not significantly affected by the
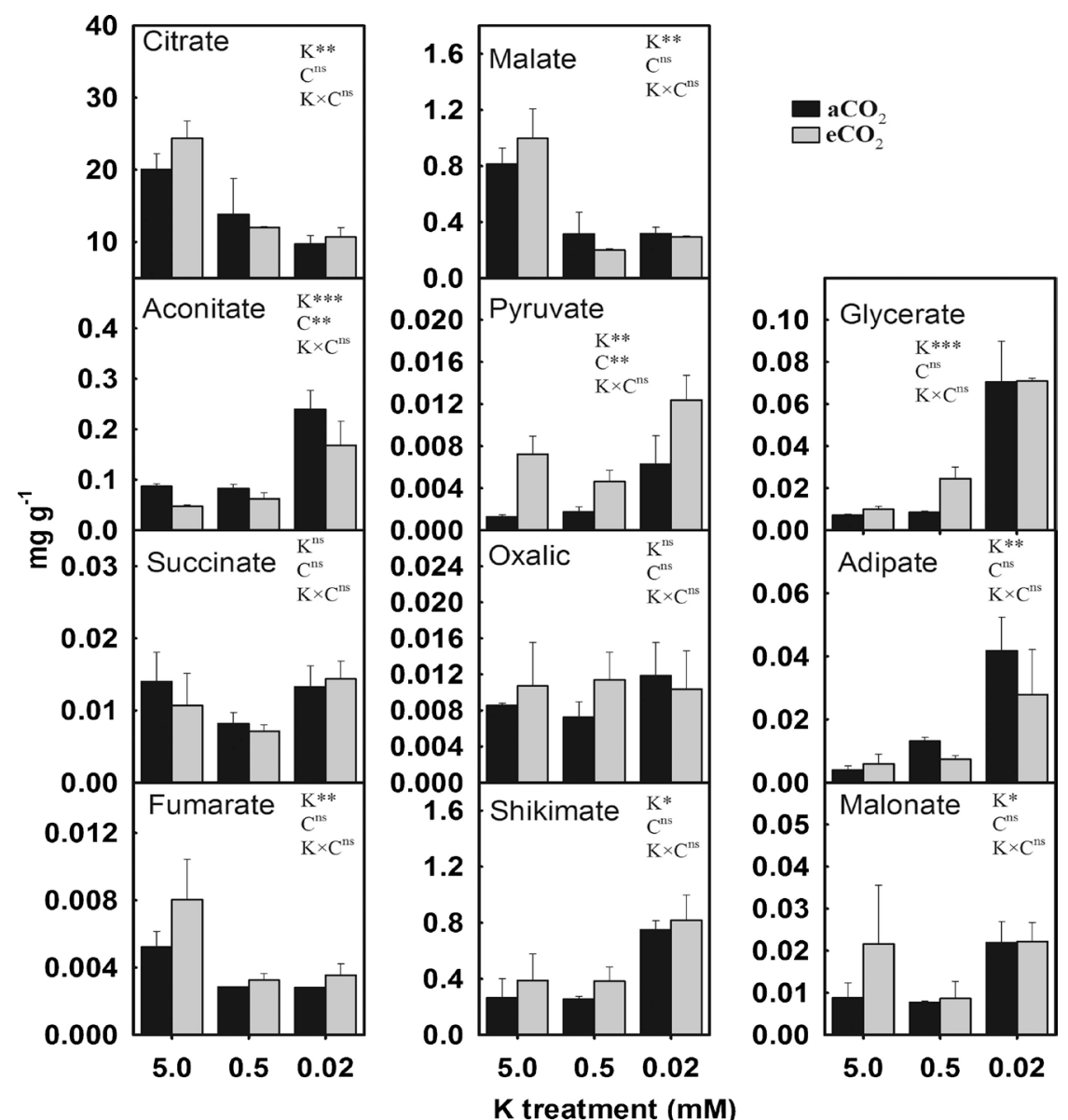

Figure 5. Potassium (K) treatment effects on the concentration of organic acids in soybean seeds grown under ambient $\left(\mathrm{aCO}_{2}, 400 \mu \mathrm{mol} \cdot \mathrm{mol}^{-1}\right.$, black bars) and elevated $\left(\mathrm{eCO}_{2}\right.$, $800 \mu \mathrm{mol} \cdot \mathrm{mol}^{-1}$, grey bars) $\mathrm{CO}_{2}$ levels. Other details are as in Figure 1. 
treatments. The moderate $\mathrm{K}$ deficiency primarily enhanced the glycerate and adipate concentrations about $92 \%$ - 105\% (Figure 5) while severe K deficiency enhanced the concentrations of shikimate, glycerate, adipate, and malonate approximately $45 \%-728 \%$. The highest and lowest increases were observed for glycerate and malonate, respectively, when averaged across $\mathrm{CO}_{2}$ levels. The $\mathrm{eCO}_{2}$ decreased aconitate concentration $24 \%$ - $45 \%$ but increased pyruvate concentration approximately $90 \%-250 \%$ across the $\mathrm{K}$ treatments (Figure 5).

\subsection{Relationship of Plant Tissue K Status with Seed Mineral Elements and Metabolic Profiles}

Figure 6 \& Figure 7 illustrate the relationship patterns between plant $\mathrm{K}$ status and concentrations of various seed constituents and ratios. The regression relationships between tissue $\mathrm{K}$ concentration and seed constituents exhibited a similar trend (decreasing or increasing) as observed due to $\mathrm{K}$ deficiency as induced by the K-deficient treatments. Out of 56 relationships ( 49 seed constituents + six ratios), 51 regression relationships of plant tissue- $\mathrm{K}$ concentration with the seed constituents (or the ratio) were significant $(P \leq 0.05)$. Out of 51 regression relationships, 20 were best described by a linear regression equation while 31 by a polynomial second order (quadratic) regression equation. However, the remaining four (Ca, S, maltose, and oxalate concentrations) did not show a significant relationship with the plant $\mathrm{K}$ concentration (Figure 6 \& Figure 7). The minerals $\mathrm{N}, \mathrm{P}, \mathrm{K}$, and their ratios, protein, oil, and fatty acids had a linear relationship with the plant $\mathrm{K}$ concentration while a quadratic relationship was observed for carbohydrates (except ribose), organic acids (except fumarate) and all amino acids. About 29 seed constituents including ratios tended to increase with a decrease in plant tissue $\mathrm{K}$ concentration. For instance, concentrations of minerals such as $\mathrm{N}, \mathrm{Cu}$, and ratios (C:P, C:K, N:P, N:K), majority of organic acids, soluble carbohydrates (except sucrose), amino acids, protein, and oleic acid increased when plant $\mathrm{K}$ concentration decreased to the minimum. Conversely, seed constituents including $\mathrm{C}, \mathrm{P}, \mathrm{K}, \mathrm{Mg}$, Oil, palmitate and essential fatty acids, citrate, and malate decreased with plant $\mathrm{K}$ concentration. The relationships also differed significantly between $\mathrm{CO}_{2}$ levels for the ratios of C:N, C:P, N:P, and $\mathrm{N}: \mathrm{K}$, and for 12 seed constituents including C, N, P, B, glucose, ribose, myo-inositol, fumarate, malate, and protein (Figure $6 \&$ Figure 7).

\section{Discussion}

\subsection{Seed Composition in Response to K Fertilization}

Influence of $\mathrm{K}$ deficiency on soybean was obvious from the substantial decline of $\mathrm{K}$ concentration in seeds and plant tissues across $\mathrm{CO}_{2}$ levels. This study revealed that soybean seeds are likely to contain deficit levels of several minerals when grown in K-deficient soils, thus affecting seed nutritional quality. Interestingly, $\mathrm{K}$ deficiency affected concentrations of several mineral elements although they were not limiting in the rooting media. Alterations in vegetative tissues and seed 

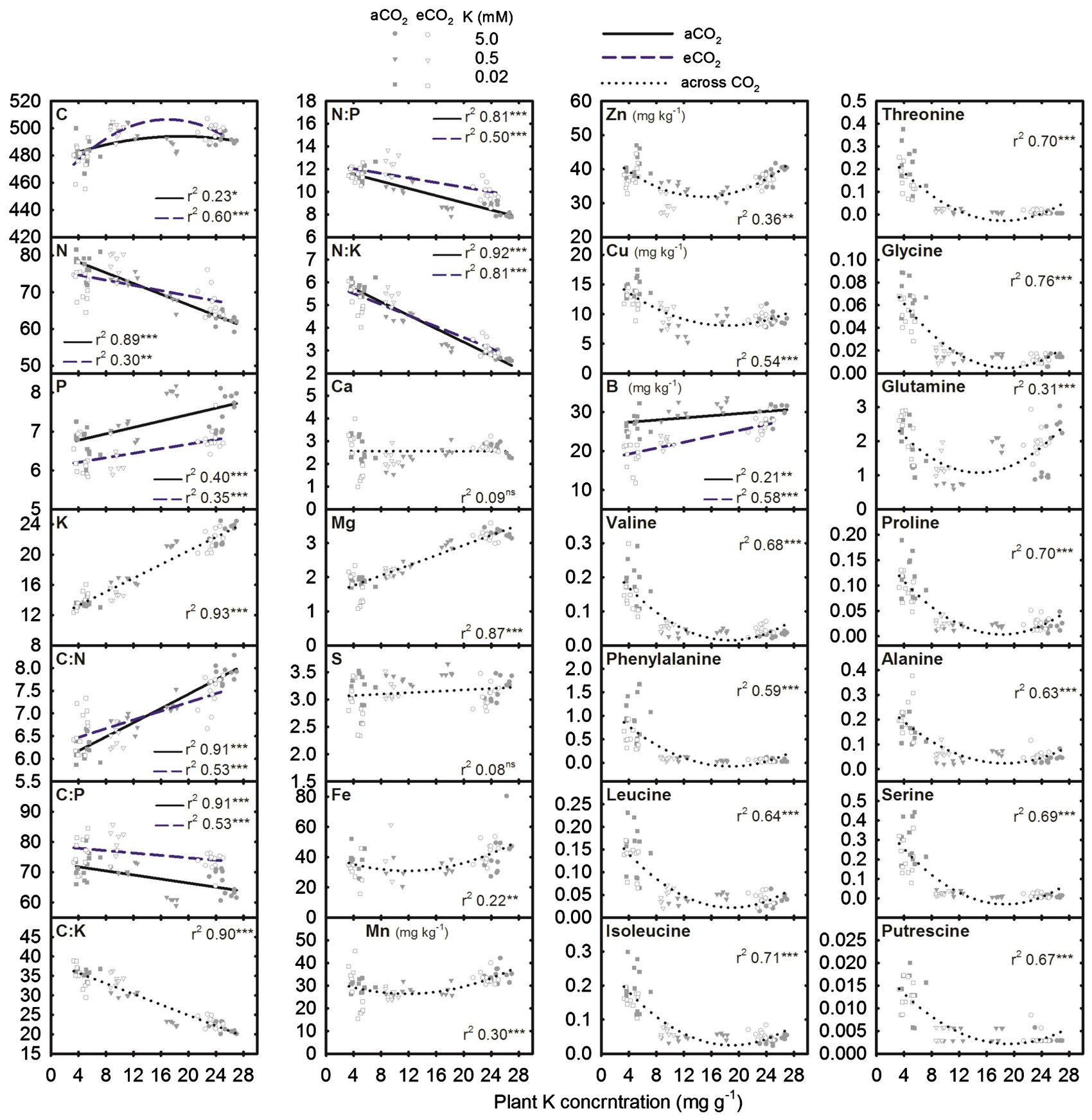

Figure 6. Relationship of whole-plant tissue potassium (K) concentration with seed mineral elements and amino acids concentrations (mg.g ${ }^{-1}$, except those marked, ratios are unitless) of soybean grown under ambient $\left(\mathrm{aCO}_{2}, 400 \mu \mathrm{mol}^{\circ} \mathrm{mol}^{-1}\right)$ and elevated $\left(\mathrm{eCO}_{2}, 800 \mu \mathrm{mol} \cdot \mathrm{mol}^{-1}\right) \mathrm{CO}_{2}$ at three $\mathrm{K}$ levels. Symbols represent individual plant measured across the repeated experiment. Lines are the fit of quadratic or linear regression equation between (solid and dashed line) or across (dotted line) $\mathrm{CO}_{2}$ levels. The regression analysis coefficient of determination $\left(\mathrm{r}^{2}\right)$ is given and the significance of level is indicated as ${ }^{*},{ }^{* *},{ }^{* *}$ and ${ }^{\mathrm{ns}}$ indicate $\mathrm{P} \leq 0.05$, $P \leq 0.01, P \leq 0.001$, non-significant $(P>0.05)$, respectively. The name of mineral elements is as in Figure 1. 

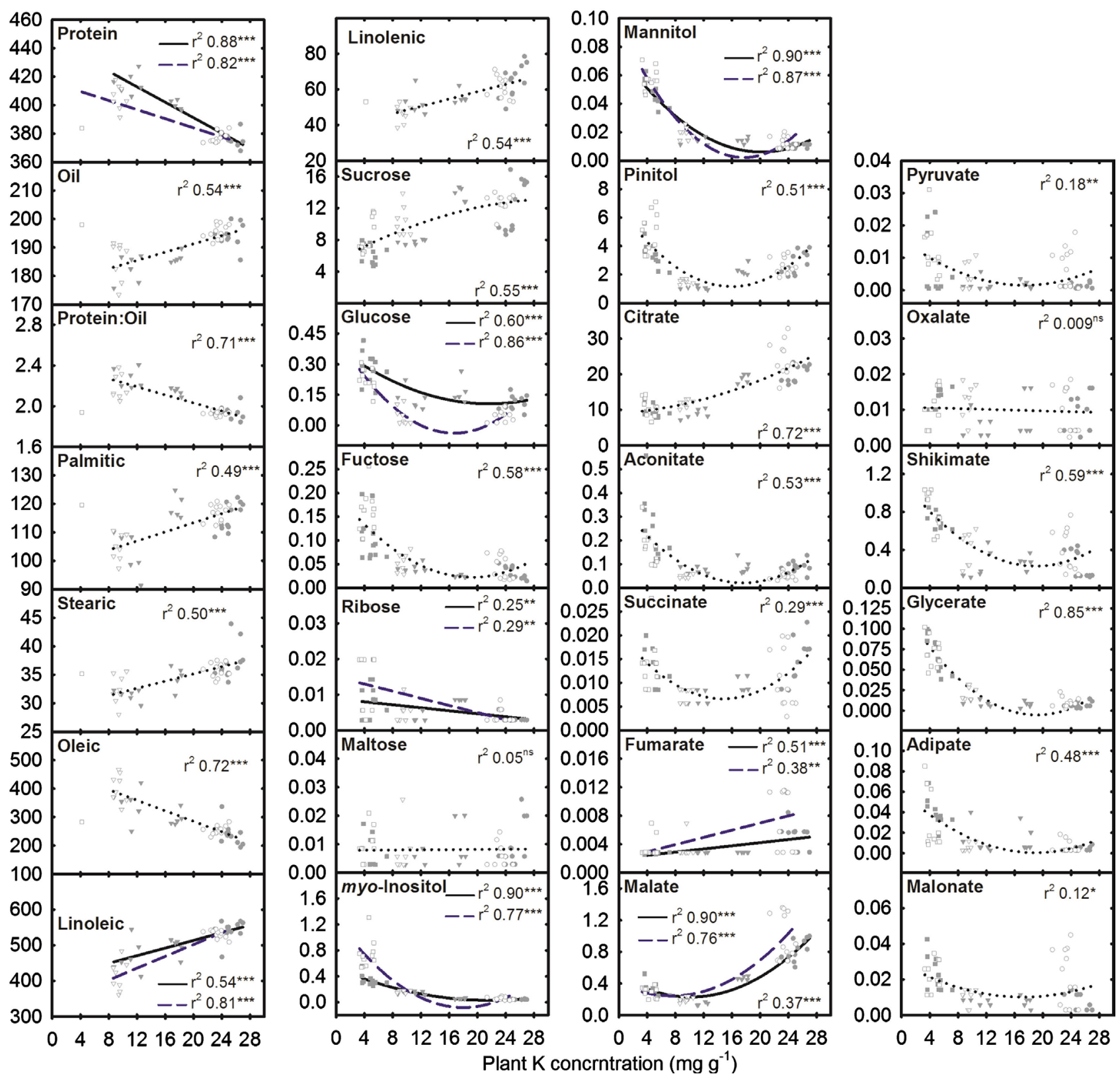

Figure 7. Relationship of whole-plant tissue potassium $(\mathrm{K})$ concentration with protein, oil, fatty acids, carbohydrates, and organic acids concentrations $\left(\mathrm{mg} \cdot \mathrm{g}^{-1}\right.$, ratio is unitless) of soybean grown under ambient $\left(\mathrm{aCO}_{2}, 400 \mu \mathrm{mol} \cdot \mathrm{mol}^{-1}\right)$ and elevated $\left(\mathrm{eCO}_{2}, 800\right.$ $\left.\mu \mathrm{mol} \cdot \mathrm{mol}^{-1}\right) \mathrm{CO}_{2}$ at three $\mathrm{K}$ levels. Symbols represent individual plant measured across the repeated experiment. Other details are as in Figure 6.

limiting conditions [27]. Similar to our study, Nelson et al. [36] reported decreased $\mathrm{Mg}$ concentration in soybean seeds under $\mathrm{K}$ deficiency. Walker et al. [35] also found significantly lower concentrations of B and $\mathrm{Zn}$ in K-deficient seeds of at least one out of five soybean cultivars tested under field conditions. Although $\mathrm{B}$ declined across $\mathrm{K}$ fertilization, $\mathrm{Zn}$ primarily decreased under the moderate $\mathrm{K}$ deficiency in this study. $\mathrm{Zn}$ is an essential nutrient in the human diet for proper function of immune systems [18].

The changes in seed mineral elements also significantly affected the ratios 
among $\mathrm{C}$ concentration and macronutrients $(\mathrm{N}, \mathrm{P}$, and $\mathrm{K})$. In $\mathrm{K}$-deficient seeds, a greater seed $\mathrm{C}: \mathrm{K}$ ratio mainly resulted from a larger decline of $\mathrm{K}$ than $\mathrm{C}$ concentration. However, greater seed $\mathrm{N}: \mathrm{P}$ and $\mathrm{N}: \mathrm{K}$ ratios were primarily caused by an increased $\mathrm{N}$ while decreased $\mathrm{K}$ and $\mathrm{P}$ concentrations under $\mathrm{K}$ deficiency. In the seeds of K-deficient soybean, the decreased C:N ratio was consistent with the previous observations [27] [36]. Moreover, a lower C:N or higher N:K ratios might have resulted from a decreased level of C-rich compounds (e.g., carbohydrates, oil) and tissue $\mathrm{K}$ concentration, respectively, without a commensurate decline or an accumulation of N-rich compounds (e.g., amino acids, protein) under $\mathrm{K}$ deficiency [27]. When plant growth is limited by macronutrients other than $\mathrm{N}$ in the rooting media (e.g., $\mathrm{K}$ ), the excess $\mathrm{N}$ in tissues are typically stored as N-rich compounds leading to an altered C:N ratio in plant tissues [27] [37] [38]. A consistent increase of amino acids (N-rich compounds) concentrations in seeds under $\mathrm{K}$ deficiency across $\mathrm{CO}_{2}$ levels was also found in this study. The glutamine was the most abundant amino acid as often reported in other studies [27] [39]. The accumulation of proline and putrescine (a polyamine) signified their role in the osmotic adjustments and desiccation avoidance under stress situations [40].

Protein and oil are considered as the major soybean seed reserves and directly contribute to the economic value [30]. However, an inverse relationship between seed protein and oil concentration observed under $\mathrm{K}$ deficiency situations indicated a trade-off between these components [21] [27] [37]. Nevertheless, increased protein concentration clearly indicated that the $\mathrm{K}$ deficiency did not limit protein synthesis in soybean seed [37]. Alternatively, K deficiency not only decreased oil concentration but also reduced the nutritive value of its fatty acids' components by decreasing accumulation of essential fatty acids (linoleic and linolenic). Gaydou and Arrivets [41] reported comparable changes in seed linoleic and linolenic acids in soybean grown across various nutrient fertilization, which was consistent with the observation made in this study.

Sucrose is the primary form of translocated photo-assimilate and is crucial for biosynthesis of protein and oil [24] [26]. Sucrose is also the most abundant soluble sugar in soybean seeds as observed across treatments in this study and elsewhere [27] [33]. Hymowitz et al. [42] studied 60 soybean lines and found that sucrose had a positive and negative correlation with oil and protein, respectively, which was consistent with their patterns observed against plant $\mathrm{K}$ concentration in this study (Figure 7). The enzymes phosphoenolpyruvate carboxylase and pyruvate kinase play important role in the carbon partitioning form sucrose to protein and oil of developing seeds, which is most likely influenced by the ratio of available amino acids and soluble carbohydrates [26] [43]. The lower sucrose concentration under $\mathrm{K}$ deficiency was accompanied by accumulation of simple sugars glucose, fructose, and ribose, and sugar alcohols, which agreed with the observations made under P deficiency [27]. Simple sugars play important role in seed germination and desiccation tolerance during seed maturation 
[44]. Accumulation of sugar alcohols such as mannitol, myo-inositol, and pinitol act as compatible solutes and help to maintain the cellular integrity of membranes, and are strongly correlated with plant tolerance to abiotic stresses [45].

Organic acids represent the stored pool of photosynthetic products and synthesized as intermediates in metabolic pathways including tricarboxylic acid cycle (TCA, i.e., reparation) and during the biosynthesis of secondary metabolites, fatty acids, and amino acids [46] [47]. Relative to the plant leaf tissues, reports on the concentrations of organic acids in crop grains/seeds are scarce, especially in nutrient-limited conditions [27] [33] [48]. The concentration of TCA intermediates citrate, malate, and fumarate decreased while pyruvate (the main substrate for TCA cycle) was enhanced under K deficiency. Generally, citrate followed by malate is the most abundant organic acid in plant tissues as also observed in this study across treatments [33] [47]. The lower seed citrate and malate concentrations under $\mathrm{K}$ deficiency contradicted the observation made under $\mathrm{P}$ deficiency, indicating a varying influence of these nutrients on the metabolic processes [27]. However, accumulation of TCA intermediate aconitate under K deficiency across $\mathrm{CO}_{2}$ levels was consistent with $\mathrm{P}$ deficiency which might result due to the depressed activity of aconitase enzyme under stress situations [27] [49]. Gupta et al. [49] also suggested that the inhibition of aconitase activity might result in enhanced biosynthesis of amino acids, as observed in this study. The accumulation of organic acids shikimate and glycerate under severe $\mathrm{K}$ deficiency was comparable to the observation made in other study [27]. Under K deficiency, the accumulation of adipate might be attributed to the breakdown of amino acid lysine [50]. The malonate also increased, especially under the severe $\mathrm{K}$ deficiency. Malonate plays role in the symbiotic fixation and might serve as the precursor of lipid biosynthesis [47].

\subsection{Seed Composition Response to $\mathrm{CO}_{2}$ Enrichment}

The $\mathrm{CO}_{2}$ significantly affected 16 seed constituents, and eight of them $(\mathrm{P}, \mathrm{S}, \mathrm{Zn}$, $\mathrm{B}$, glucose, aconitate, linoleic, and linolenic acids) had lower values while six (fructose, myo-inositol, mannitol, pyruvate, alanine, and oleic acid) had higher values under $\mathrm{eCO}_{2}$ versus $\mathrm{aCO}_{2}$ consistently across $\mathrm{K}$ fertilization. However, differential sensitivity to $\mathrm{eCO}_{2}$ in the concentration of several seed components was found because of the varying degree of responses among three $\mathrm{K}$ fertilization resulting in a $\mathrm{K} \times \mathrm{CO}_{2}$ interaction. For instance, the concentration of essential amino acids (e.g., valine and phenylalanine) tended to be greater at $\mathrm{eCO}_{2}$ versus $\mathrm{aCO}_{2}$ under the control or moderate $\mathrm{K}$ fertilization but declined under severe $\mathrm{K}$ deficiency. Likewise, the $\mathrm{eCO}_{2}$-mediated accumulation of fructose and myoinositol was relatively much greater under severe $\mathrm{K}$ deficiency than other $\mathrm{K}$ levels. The $\mathrm{eCO}_{2}$ also increased the C:P and N:P ratio in soybean seeds, particularly when the $\mathrm{K}$ deficiency was not severe, and agreed with the previous observations [27] [51].

Lower concentrations of mineral nutrients and metabolites in plant tissues 
under $\mathrm{eCO}_{2}$ have often been reported and found to vary between species, cultivars, and growing environments [3] [15] [16] [17] [27] [51]. Over the decades, dilution effects due to increased photosynthates, plant size, and leaf thickness, lower transpiration, and adjustment in the nutrient uptake and utilization have emerged as the nature of the decreased concentrations of minerals and other constituents in plant tissues under $\mathrm{eCO}_{2}$ [16] [17] [19] [51]. Furthermore, an altered $\mathrm{N}$ metabolism under $\mathrm{eCO}_{2}$ also influences biosynthesis of organic compounds, thus affecting the overall metabolic response of plants to $\mathrm{eCO}_{2}$ [52]. Therefore, the inconsistent impacts of $\mathrm{eCO}_{2}$ on various seed constituents suggested the existence of a combination of mechanisms contributing to the changes observed in this study. The insignificant effect of $\mathrm{eCO}_{2}$ on the seed oil and protein concentrations have also been reported in soybean and other crops [15] [16]. However, $\mathrm{eCO}_{2}$ changed the composition of fatty acids by enhancing oleic acid but decreasing linoleic and linolenic acids (essential fatty acid), especially under $\mathrm{K}$ deficiency. Högy et al. [53] also found decreasing trends in these essential fatty acids under $\mathrm{eCO}_{2}$ in the Brassica sp., which indicates negative impacts of $\mathrm{CO}_{2}$ enrichment on the seed nutritive values.

\section{Conclusion}

The study showed that the soybean seed compositions were affected more by $\mathrm{K}$ deficiency than $\mathrm{CO}_{2}$ enrichment. $\mathrm{K}$ fertilization influenced 41 out of 49 seed constituents measured and more than half of them increased while about 16 constituents declined under $\mathrm{K}$ deficiency. Thus, $\mathrm{K}$ deficiency affected concentrations of seed constituents primarily by diminishing mineral elements, oil, and essential fatty acids but enhancing the accumulation of majority of other components including protein, amino acids, simple sugars, and stress responsive metabolites such as sugar alcohols, glycerate, putrescene, and proline. The $\mathrm{CO}_{2}$ also affected 16 out of 49 seed constituents and decreased several mineral elements and essential fatty acids. However, concentration of essential amino acids (e.g., valine, phenylalanine, leucine) declined at $\mathrm{eCO}_{2}$, exclusively under the severe $\mathrm{K}$ deficiency, exhibiting a $\mathrm{K} \times \mathrm{CO}_{2}$ interaction. The results showed that $\mathrm{eCO}_{2}$ is likely to exacerbate negative impacts of $\mathrm{K}$ deficiency on soybean seed nutritional quality, especially, by reducing the levels of minerals elements and fatty acids. Since essential amino acids and fatty acids paly crucial role in human diet, investigation of interactive impacts of $\mathrm{K}$ deficiency and $\mathrm{eCO}_{2}$ on the seed nutritional quality merit further attention on other cultivars and crops.

\section{Acknowledgements}

The authors thank Darryl Baxam (Engineering Technician) for help in maintaining the controlled environment facility, Robert Erdman for assisting in the metabolite measurements, and Mariam Manzoor for aiding in plant care. Thanks also goes to our colleagues at the National Center for Agricultural Utilization Research, USDA-ARS, Peoria, IL, USA for the determination of seed pro- 
tein, oil, and fatty acids.

\section{Conflicts of Interest}

The authors declare no conflicts of interest regarding the publication of this paper.

\section{References}

[1] Medic, J., Atkinson, C. and Hurburgh, C.R. (2014) Current Knowledge in Soybean Composition. Journal of the American Oil Chemists' Society, 91, 363-384.

https://doi.org/10.1007/s11746-013-2407-9

[2] Rotundo, J.L. and Westgate, M.E. (2009) Meta-Analysis of Environmental Effects on Soybean Seed Composition. Field Crops Research, 110, 147-156. https://doi.org/10.1016/j.fcr.2008.07.012

[3] Zhu, C., Kobayashi, K., Loladze, I., Zhu, J., Jiang, Q., Xu, X., et al. (2018) Carbon Dioxide $\left(\mathrm{CO}_{2}\right)$ Levels This Century Will Alter the Protein, Micronutrients, and Vitamin Content of Rice Grains with Potential Health Consequences for the Poorest Rice-Dependent Countries. Science Advances, 4, eaaq1012. https://doi.org/10.1126/sciadv.aaq1012

[4] Smil, V. (1999) Crop Residues: Agriculture's Largest Harvest. Bioscience, 49, 299-308. https://doi.org/10.2307/1313613

[5] Römheld, V. and Kirkby, E. (2010) Research on Potassium in Agriculture: Needs and Prospects. Plant and Soil, 335, 155-180. https://doi.org/10.1007/s11104-010-0520-1

[6] Sardans, J. and Peñuelas, J. (2015) Potassium: A Neglected Nutrient in Global Change. Global Ecology and Biogeography, 24, 261-275.

https://doi.org/10.1111/geb.12259

[7] IPCC (2013) Climate Change 2013: The Physical Science Basis. In: Stocker, T.F., Qin, D., Plattner, G.-K., Tignor, M., Allen, S.K., Boschung, J., Nauels, A., Xia, Y., Bex, V. and Midgley, P.M., Eds., Contribution of Working Group I to the Fifth Assessment Report of the Intergovernmental Panel on Climate Change, Cambridge University Press, Cambridge, United Kingdom and New York, 1535 pp.

[8] Taub, D. (2010) Effects of Rising Atmospheric Concentrations of Carbon Dioxide on Plants. Nature Education Knowledge, 3, 21.

[9] Reddy, K.R. and Zhao, D.L. (2005) Interactive Effects of Elevated $\mathrm{CO}_{2}$ and Potassium Deficiency on Photosynthesis, Growth, and Biomass Partitioning of Cotton. Field Crops Research, 94, 201-213. https://doi.org/10.1016/j.fcr.2005.01.004

[10] Singh, S.K. and Reddy, V.R. (2018) Co-Regulation of Photosynthetic Processes under Potassium Deficiency across $\mathrm{CO}_{2}$ Levels in Soybean: Mechanisms of Limitations and Adaptations. Photosynthesis Research, 137, 183-200. https://doi.org/10.1007/s11120-018-0490-3

[11] Singh, S.K. and Reddy, V.R. (2017) Potassium Starvation Limits Soybean Growth More Than the Photosynthetic Processes across $\mathrm{CO}_{2}$ Levels. Frontiers in Plant Science, 8, 991. https://doi.org/10.3389/fpls.2017.00991

[12] Bellaloui, N., Yin, X., Mengistu, A., McClure, A.M., Tyler, D.D. and Reddy, K.N. (2013) Soybean Seed Protein, Oil, Fatty Acids, and Isoflavones Altered by Potassium Fertilizer Rates in the Midsouth. American Journal of Plant Sciences, 4, 13.

https://doi.org/10.4236/ajps.2013.45121 
[13] Krueger, K., Goggi, A.S., Mallarino, A.P. and Mullen, R.E. (2013) Phosphorus and Potassium Fertilization Effects on Soybean Seed Quality and Composition. Crop Science, 53, 602-610. https://doi.org/10.2135/cropsci2012.06.0372

[14] Asif, M., Tunc, C.E. and Ozturk, L. (2018) Changes in Yield Attributes and K Allocation in Wheat as Affected by $\mathrm{K}$ Deficiency and Elevated $\mathrm{CO}_{2}$. Plant and Soil, 426, 153-162. https://doi.org/10.1007/s11104-018-3603-Z

[15] Loladze, I. (2014) Hidden Shift of the Ionome of Plants Exposed to Elevated $\mathrm{CO}_{2}$ Depletes Minerals at the Base of Human Nutrition. eLife, 3, e02245. https://doi.org/10.7554/eLife.02245

[16] Myers, S.S., Zanobetti, A., Kloog, I., Huybers, P., Leakey, A.D.B., Bloom, A.J., et al. (2014) Increasing $\mathrm{CO}_{2}$ Threatens Human Nutrition. Nature, 510, 139-142. https://doi.org/10.1038/nature13179

[17] Högy, P., Brunnbauer, M., Koehler, P., Schwadorf, K., Breuer, J., Franzaring, J., et al. (2013) Grain Quality Characteristics of Spring Wheat (Triticum Aestivum) as Affected by Free-Air $\mathrm{CO}_{2}$ Enrichment. Environmental and Experimental Botany, 88, 11-18. https://doi.org/10.1016/j.envexpbot.2011.12.007

[18] Myers, S.S., Wessells, K.R., Kloog, I., Zanobetti, A. and Schwartz, J. (2015) Effect of Increased Concentrations of Atmospheric Carbon Dioxide on the Global Threat of Zinc Deficiency: A Modelling Study. The Lancet Global Health, 3, e639-e645. https://doi.org/10.1016/S2214-109X(15)00093-5

[19] Taub, D.R. and Wang, X. (2008) Why Are Nitrogen Concentrations in Plant Tissues Lower under Elevated $\mathrm{CO}_{2}$ ? A Critical Examination of the Hypotheses. Journal of Integrative Plant Biology, 50, 1365-1374. https://doi.org/10.1111/j.1744-7909.2008.00754.x

[20] Marschner, H. (1986) Mineral Nutrition of Higher Plants. Academic Press, Orlando, FL.

[21] Yin, X. and Vyn, T.J. (2003) Potassium Placement Effects on Yield and Seed Composition of No-Till Soybean Seeded in Alternate Row Widths. Agronomy Journal, 95, 126-132. https://doi.org/10.2134/agronj2003.0126

[22] Cakmak, I. (2005) The Role of Potassium in Alleviating Detrimental Effects of Abiotic Stresses in Plants. Journal of Plant Nutrition and Soil Science, 168, 521-530. https://doi.org/10.1002/jpln.200420485

[23] Merle, T., Ershad, T. and Bálint, J. (2018) Functioning of Potassium and Magnesium in Photosynthesis, Photosynthate Translocation and Photoprotection. Physiologia Plantarum, 163.

[24] Fader, G.M. and Koller, H.R. (1985) Seed Growth Rate and Carbohydrate Pool Sizes of the Soybean Fruit. Plant Physiology, 79, 663-666. https://doi.org/10.1104/pp.79.3.663

[25] Rotundo, J.L., Borrás, L., Westgate, M.E. and Orf, J.H. (2009) Relationship between Assimilate Supply Per Seed During Seed Filling and Soybean Seed Composition. Field Crops Research, 112, 90-96. https://doi.org/10.1016/j.fcr.2009.02.004

[26] Smith, A.J., Rinne, R.W. and Seif, R.D. (1989) Phosphoenolpyruvate Carboxylase and Pyruvate Kinase Involvement in Protein and Oil Biosynthesis during Soybean Seed Development. Crop Science, 29, 349-353. https://doi.org/10.2135/cropsci1989.0011183X002900020024x

[27] Singh, S.K., Barnaby, J.Y., Reddy, V.R. and Sicher, R.C. (2016) Varying Response of the Concentration and Yield of Soybean Seed Mineral Elements, Carbohydrates, Organic Acids, Amino Acids, Protein, and Oil to Phosphorus Starvation and $\mathrm{CO}_{2}$ 
Enrichment. Frontiers in Plant Science, 7, 1967. https://doi.org/10.3389/fpls.2016.01967

[28] Ignace, D. (2007) Novel Soybean Oil Products for a Healthier Nutrition-Recent Developments, Market Introduction and Targeted Commercialization. Lipid Technology, 19, 128-131. https://doi.org/10.1002/lite.200700044

[29] Hartman, G.L., West, E.D. and Herman, T.K. (2011) Crops That Feed the World 2. Soybean-Worldwide Production, Use, and Constraints Caused by Pathogens and Pests. Food Security, 3, 5-17. https://doi.org/10.1007/s12571-010-0108-x

[30] Pettigrew, W.T. (2008) Potassium Influences on Yield and Quality Production for Maize, Wheat, Soybean and Cotton. Physiologia Plantarum, 133, 670-681. https://doi.org/10.1111/j.1399-3054.2008.01073.x

[31] Plank, C.O. (1992) Plant Analysis Reference Procedures for the Southern Region of the United States. Southern Cooperative Series Bulletin 368. University of GA, Athens, GA, 68.

[32] Singh, S.K., Reddy, V.R., Sharma, M.P. and Agnihotri, R. (2015) Dynamics of Plant Nutrients, Utilization and Uptake, and Soil Microbial Community in Crops under Ambient and Elevated Carbon Dioxide. In: Rakshit, A., Singh, H.B. and Sen, A., Eds., Nutrient Use Efficiency. From Basics to Advances, Springer India, New Delhi, 381-399. https://doi.org/10.1007/978-81-322-2169-2 24

[33] Xu, G., Singh, S., Barnaby, J., Buyer, J., Reddy, V. and Sicher, R. (2016) Effects of Growth Temperature and Carbon Dioxide Enrichment on Soybean Seed Components at Different Stages of Development. Plant Physiology and Biochemistry, 108, 313-322. https://doi.org/10.1016/j.plaphy.2016.07.025

[34] Singh, S.K., Hoyos-Villegas, V., Houx Iii, J.H. and Fritschi, F.B. (2012) Influence of Artificially Restricted Rooting Depth on Soybean Yield and Seed Quality. Agricultural Water Management, 105, 38-47. https://doi.org/10.1016/j.agwat.2011.12.025

[35] Walker, W.M., Raines, G.A. and Peck, T.R. (1985) Effect of Soybean Cultivar, Phosphorus and Potassium upon Yield and Chemical Composition. Journal of Plant Nutrition, 8, 73-87. https://doi.org/10.1080/01904168509363325

[36] Nelson, W.L., Burkhart, L. and Colwell, W.E. (1946) Fruit Development, Seed Quality, Chemical Composition, and Yield of Soybeans as Affected by Potassium and Magnesium. Soil Science Society of America Journal, 10, 224-229. https://doi.org/10.2136/sssaj1946.03615995001000C00037x

[37] Sale, P.W.G. and Campbell, L.C. (1986) Yield and Composition of Soybean Seed as a Function of Potassium Supply. Plant and Soil, 96, 317-325. https://doi.org/10.1007/BF02375136

[38] Staswick, P.E., Huang, J.-F. and Rhee, Y. (1991) Nitrogen and Methyl Jasmonate Induction of Soybean Vegetative Storage Protein Genes. Plant Physiology, 96, 130-136. https://doi.org/10.1104/pp.96.1.130

[39] Yemane, A. and Skjelvåg, A.O. (2003) Effects of Fertilizer Phosphorus on Yield Traits of Dekoko (Pisum Sativum Var. Abyssinicum) under Field Conditions. Journal of Agronomy and Crop Science, 189, 14-20. https://doi.org/10.1046/j.1439-037X.2003.00595.x

[40] Bouchereau, A., Aziz, A., Larher, F. and Martin-Tanguy, J. (1999) Polyamines and Environmental Challenges: Recent Development. Plant Science, 140, 103-125. https://doi.org/10.1016/S0168-9452(98)00218-0

[41] Gaydou, E.M. and Arrivets, J. (1983) Effects of Phosphorus, Potassium, Dolomite, and Nitrogen Fertilization on the Quality of Soybean. Yields, Proteins, and Lipids. 
Journal of Agricultural and Food Chemistry, 31, 765-769. https://doi.org/10.1021/jf00118a022

[42] Hymowitz, T., Collins, F.I., Panczner, J. and Walker, W.M. (1972) Relationship between the Content of Oil, Protein, and Sugar in Soybean Seed. Agronomy Journal, 64, 613-616. https://doi.org/10.2134/agronj1972.00021962006400050019x

[43] Meyer, K. and Kinney, A.J. (2010) Biosynthesis and Biotechnology of Seed Lipids Including Sterols, Carotenoids and Tocochromanols. In: Wada, H. and Murata, N., Eds., Lipids in Photosynthesis. Essential and Regulatory Functions, Springer Netherlands, Dordrecht, 407-444. https://doi.org/10.1007/978-90-481-2863-1 19

[44] Obendorf, R.L. and Kosina, S.M. (2011) Soluble Carbohydrates in Soybean. In: Rijeka, C., Ed., Soybean-Biochemistry, Chemistry and Physiology, InTech Open, London. https://doi.org/10.5772/15110 http://www.intechopen.com/articles/show/title/soluble-carbohydrates-in-soybean

[45] Thomas, J.C., Sepahi, M., Arendall, B. and Bohnert, H.J. (1995) Enhancement of Seed Germination in High Salinity by Engineering Mannitol Expression in Arabidopsis Thaliana. Plant, Cell \& Environment, 18, 801-806. https://doi.org/10.1111/j.1365-3040.1995.tb00584.x

[46] Nelson, D.L. and Cox, M.M. (2008) Lehninger Principles of Biochemistry. 5th Edition, W. H. Freeman Macmillan, New York.

[47] Igamberdiev, A.U. and Eprintsev, A.T. (2016) Organic Acids: The Pools of Fixed Carbon Involved in Redox Regulation and Energy Balance in Higher Plants. Frontiers in Plant Science, 7, 1042. https://doi.org/10.3389/fpls.2016.01042

[48] Barnaby, J.Y., Fleisher, D., Reddy, V. and Sicher, R. (2015) Combined Effects of $\mathrm{CO}_{2}$ Enrichment, Diurnal Light Levels and Water Stress on Foliar Metabolites of Potato Plants Grown in Naturally Sunlit Controlled Environment Chambers. Physiologia Plantarum, 153, 243-252. https://doi.org/10.1111/ppl.12238

[49] Gupta, K.J., Shah, J.K., Brotman, Y., Jahnke, K., Willmitzer, L., Kaiser, W.M., et al. (2012) Inhibition of Aconitase by Nitric Oxide Leads to Induction of the Alternative Oxidase and to a Shift of Metabolism Towards Biosynthesis of Amino Acids. Journal of Experimental Botany, 63, 1773-1784. https://doi.org/10.1093/jxb/ers053

[50] Falco, S.C., Guida, T., Locke, M., Mauvais, J., Sanders, C., Ward, R.T., et al. (1995) Transgenic Canola and Soybean Seeds with Increased Lysine. Biotechnology, 13, 577. https://doi.org/10.1038/nbt0695-577

[51] Gifford, R., Barrett, D. and Lutze, J. (2000) The Effects of Elevated $\left[\mathrm{CO}_{2}\right]$ on the C:N and C:P Mass Ratios of Plant Tissues. Plant and Soil, 224, 1-14.

https://doi.org/10.1023/A:1004790612630

[52] Bloom, A.J., Burger, M., Asensio, J.S.R. and Cousins, A.B. (2010) Carbon Dioxide Enrichment Inhibits Nitrate Assimilation in Wheat and Arabidopsis. Science, 328, 899-903. https://doi.org/10.1126/science.1186440

[53] Högy, P., Franzaring, J., Schwadorf, K., Breuer, J., Schütze, W. and Fangmeier, A. (2010) Effects of Free-Air $\mathrm{CO}_{2}$ Enrichment on Energy Traits and Seed Quality of Oilseed Rape. Agriculture, Ecosystems \& Environment, 139, 239-244.

https://doi.org/10.1016/j.agee.2010.08.009 